\title{
Occurrence of Coagulase-negative Staphylococcal mastitis in dairy cows
}

\author{
Mohamed El-Diasty ${ }^{1}$, Hager Talaat ${ }^{1^{*}}$, Samar Atwa ${ }^{2}$, Elzahraa Elbaz ${ }^{2}$, Mohamed Eissa ${ }^{3}$ \\ ${ }^{1}$ Animal Health Research Institute- Mansoura, Egypt. \\ ${ }^{2}$ Department of Internal Medicine, Infections and Fish Diseases, Faculty of Veterinary Medicine, Mansoura University, Mansoura \\ 35516, Egypt. \\ ${ }^{3}$ Department of Animal Medicine, Faculty of Veterinary Medicine, Zagazig University, P.O. 44519, Zagazig, Egypt.
}

\section{ARTICLE HISTORY}

Received: 15.08 .2019

Revised: 22.09.2019

Accepted: 24.09.2019

Address correspondence to Hager Talaat; Tel: +201006683019;

Fax: +20502200696

E-mail: hager.tal3at@gmail.com

\section{ABSTRACT}

\begin{abstract}
Objective: To study the prevalence of Coagulase-negative Staphylococci in clinical and subclinical mastitis in dairy cows.

Design: Case-control study.

Animals: 415 lactating Holstein cows.

Procedures: A total of 896 quarter milk samples were collected aseptically from 415 dairy cows for bacteriological examination (mastitic cows, $n=50$; healthy cows, $n=174$ ). Identification of different bacterial isolates followed by antibiotic sensitivity test for Coagulase-negative Staphylococci (CNS) was carried out, using disc-diffusion method against 13 different antibiotics .

Results: 224 out of 415 cows (54\%) were proven to be mastitic (12\% clinical mastitis, 42 $\%$ subclinical mastitis). Coagulase-negative Staphylococci were the prevalent isolate (32\%). CNS was recorded in $25.7 \%$ of clinical cases and $34 \%$ of subclinical mastitis. The antibiogram of CNS isolates against 13 different antibiotics revealed high level of resistance to ampicillin (85\%) and oxacillin (85\%). However, they were less resistant to vancomycin (5\%). The other antibiotics showed variable levels of resistance ranging from 40-75\%.

Conclusion and clinical relevance: Coagulase-negative Staphylococci were the most common bacteria isolated from mastitic cases. Multi-drug resistance was observed among CNS with high resistance to ampicillin and penicillin, so the use of such B-lactam antibiotics should be restricted specially if there were suspected cases of Coagulasenegative Staphylococci.
\end{abstract}

Keywords: Mastitis, Coagulase-negative Staphylococci, Antibiogram, Cows.

\section{INTRODUCTION}

Mastitis is one of the most costly diseases of the dairy cattle in Egypt [1]. Mastitis adversely decrease both quality and quantity of the milk [2]. According to symptoms, mastitis can be categorized into two forms, which are clinical and subclinical. The clinical form is characterized by one or more of visible signs in the udder as edema, pain, redness, hotness and can be associated with changes in the milk. It may be accompanied with general systemic disorders. On the other hand, the subclinical form has no visible signs so, it is called "the silent form" [3].

Several previous researches have been reported the prevalence rate of mastitis at the cattle $50 \%$ and at the quarter level $10-25 \%$ [4]. Bovine subclinical mastitis is the predominant form of mastitis in lactating cattle, exceeding $20-50 \%$ of cows in a given herd [5], it is considered 40-50 times more prevalent than clinical form and it acts as a reservoir for microorganisms that can be transmitted to other animals within the farm due to contagious nature of the disease $[6,7]$.

More than 140 different microorganisms have been isolated from bovine mastitis cases. The most common causative agents of mastitis are bacteria which can be classified as contagious pathogens including (Staphylococcus aureus and Streptococcus agalactiae, Corynbacteruim bovis and Mycoplasma spp.) or environmental pathogens include Esherichia coli, Enterococcus faecalis, Streptococcus dysgalactiae and Streptococcus uberis and CNS [8].

Contagious mastitis pathogens are generally transmitted from cow to another with the infected glands being the primary source of the infection, via milk-contaminated fomites at milking, milkers and by milking machine [9], while environmental mastitis pathogens are found in the surroundings of the cow. Their mode of transmission is from the environment to the cow under unhygienic measures as contaminated soil or wet bedding [10]. Recently, CNS have turned out to be the most common bacterial isolates of mastitis in cattle in several countries and are considered as emerging mastitis pathogens [11]. They can cause persistent intramammary infections, which lead to elevated somatic cell count in milk (SCC) and decreased milk quality [12]. Till now, more than 15 CNS spp. have been identified that cause mastitis in dairy cattle, but S. chromogenes, S. xylosus, S. simulans, S. epidermidis, S. haemolyticus and $S$. hyicus are the most commonly isolated CNS from bovine mastitis $[13,14]$.

Antimicrobial chemotherapy is the primary approach for treatment of staphylococcal mastitis in cattle [15]. Sensitivity tests have been used as a guide for the veterinarians to select the most suitable antimicrobial agent [16]. The indiscriminate and continuous use of antimicrobials, without medical prescription or accurate identification of the microbial agent, can result in high resistance of CNS, which makes dealing with mastitis treatment more challenging [17]. 
Carriage of antibiotic resistance genes by CNS species can be a potential source for gene transmission, indicating the importance of detection of such resistance genes [18]. The emergence of Staphylococcal species resistant to penicillin and ampicillin have become a worldwide phenomenon due to misuse of beta -lactam antibiotics in the treatment of mastitis [19]. Moreover, high levels of resistance to penicillin is followed by the development of bacterial isolates resistant to the semi-synthetic penicillins (methicillin and oxacillin), tetracyclines, macrolides and aminoglycosides has made the treatment of diseases caused by Staphylococci a global challenge [20]. Thus, this study aimed to investigate the prevalence of CNS in clinical and subclinical mastitis in dairy cows and their antibiogram.

\section{MATERIALS AND METHODS}

\subsection{Animals and study area}

A total number of 415 lactating Holstein cows (a cross breed) from different localities in Egypt were examined for clinical and subclinical mastitis during the period from October 2014 to June 2018. 345 cows out of 415 cows were collected from four private dairy farms at Damietta (farm A, 60 lactating cows, farm B, 65 lactating cows and farm C, 120 lactating cows) and El-Sharkia (farm D, 100 lactating cow) governorates in addition to, while, the remaining cows (70) were as individual cases of dairy cows at ElDakahlia governorate;. Clinical examination of the investigated lactating cows was done according to [21] to estimate the presence of any signs of inflammation for detection of clinical mastitis cases also, California Mastitis Test (CMT) was performed as a screening test for detection of subclinical mastitis according to [22].

\subsection{Experimental design}

Our study was designed to detect the prevalence of mastitis (clinical and subclinical forms) and its causative bacteria either contagious or environmental among 415 lactating Holstein cows at Damietta, El-Sharkia and El-Dakahlia governorates. The experiment was focused on the isolated coagulase negative Staphylococci, identification of each isolate and their sensitivity to different antibiotics.

2.3 Collection of milk samples and Bacteriological examination of milk samples

A total of 896 quarter milk samples were collected from clinical and apparently healthy 415 lactating Holstein cows for bacteriological examination. A total number of clinical cases was 50 cows, and not all quarters were affected Milk samples collection was achieved aseptically according to [23].

Milk culturing and identification were performed according to [24] at the laboratory of Animal Health Research Institute, Mansoura Provincial Lab., Egypt. Classification of bacteria was performed by standard biochemical tests according to [24].

\subsection{Antimicrobial sensitivity test}

The antibiogram was done according to [25] by disc-diffusion method for the isolated CNS against 13 antibiotics (Oxoid). CNS isolates were tested against ampicillin ( $\mathrm{AM} ; 10 \mu \mathrm{g}$ ), ampicillin/sulbactam (SAM; 10/10 $\mu \mathrm{g}$ ), cefotaxime (CTX; $30 \mu \mathrm{g}$ ), cefoxitin (FOX; $30 \mu \mathrm{g}$ ), chloramphenicol (C; $30 \mu \mathrm{g}$ ), ciprofloxacin $(\mathrm{CIP} ; 5 \mu \mathrm{g})$, erythromycin $(\mathrm{E} ; 15 \mu \mathrm{g})$, gentamicin (CN; $10 \mu \mathrm{g})$, ofloxacin (OFX; $5 \mu \mathrm{g})$, oxacillin (OX; $1 \quad \mu \mathrm{g})$, sulphamethoxazole/trimethoprim (SXT; 23.75/1.25 $\mu \mathrm{g}$ ), tetracycline (TE; $30 \mu \mathrm{g})$ and vancomycin (VA; $30 \mu \mathrm{g})$. The interpretation of the results was applied according to the National Committee for Clinical Laboratory Standards Institute, 2014 [26].

\section{RESULTS}

In table (1), the prevalence of clinical and subclinical mastitis in the different dairy farms was presented. Out of 415 examined lactating cows, the overall prevalence rate of mastitis at cattle level was $54 \%(224 / 415)$, of which $12 \%$ (50/415) were clinical mastitis and $42 \%(174 / 415)$ were subclinical mastitis. The prevalence rate of mastitis at the quarter level was $52.1 \%$ (467/896) of which $11.8 \%(106 / 896)$ and $40.3 \%$ (361/896) were clinical and subclinical form, respectively.

In table (2), Bacteriological examination of milk samples from clinical and subclinical mastitic cows was demonstrated. Coagulase negative Staphylococci were the predominant bacteria isolated from mastitic cases (32\%) followed by E. coli $(24.8 \%)$, S. aureus (15.4\%), Str. agalactiae (13.4\%), Str .dysgalactiae (8.8\%), E. faecalis $(2 \%)$, Str. uberis (2\%), Enterobacter aerogenes $(0.66 \%)$, Micrococcus (0.66\%), Enterobacter agglomerans $(0.22 \%)$ and Klebsiella spp. (0.22\%).

In table (3), the antibiogram of Coagulase-negative Staphylococci isolated from mastitic milk samples was shown. Concerning coagulase negative staphylococci isolates as shown in Table (16), they were highly resistant to Ampicillin (85\%) and Oxacillin (85\%), followed by Cefoxitin (75\%), Sulphamethoxazole/ Trimethoprim (75\%), Cefotaxime (70\%), Tetracycline (65\%), Ampicillin/Sulbactam (60\%), Erythromycin (60\%), Chloramphenicol (45\%), Gentamicin (45\%), Ofloxacin (45\%), Ciprofloxacin (40\%) and finally Vancomycin (5\%).

Table 1. Prevalence of clinical and subclinical mastitis in dairy cattle in the different dairy farms.

$\begin{array}{lllll}\text { Province } & \text { Farm } & \begin{array}{l}\text { Examined } \\ \text { animals } \\ (\mathrm{n}=415)\end{array} & \begin{array}{l}\text { Clinical } \\ \text { mastitis } \\ (\mathrm{n}=50)\end{array} & \begin{array}{l}\text { Subclinical } \\ \text { mastitis } \\ (\mathrm{n}=174)\end{array} \\ \text { Damietta } & \text { Farm A } & 60 & 12(20 \%) & 27(45 \%) \\ \text { Damietta } & \text { Farm B } & 65 & - & 31(47.6 \%) \\ \text { Damietta } & \text { Farm C } & 120 & 3(25 \%) & 27(22.5 \%) \\ \text { El -Sharkia } & \text { Farm D } & 100 & 4(4 \%) & 60(60 \%) \\ \text { El-Dakahlia } & \text { Smallholders } & 70 & 31(44.2 \%) & 29(41.4 \%)\end{array}$

Table 2. Prevalence of different bacterial isolates recovered from clinical \& subclinical mastitic milk samples of dairy cows.

\begin{tabular}{|c|c|c|c|}
\hline Isolated microorganisms & $\begin{array}{l}\text { Total } \\
\text { Isolates } \\
(n=456)\end{array}$ & $\begin{array}{l}\text { Clinical } \\
\text { mastitis } \\
(n=105)\end{array}$ & $\begin{array}{l}\text { Subclinical } \\
\text { mastitis } \\
(n=351)\end{array}$ \\
\hline S. aureus $(n=70)$ & $15.4 \%$ & $\begin{array}{l}15 \\
(14.3 \%)\end{array}$ & $55(15.7 \%)$ \\
\hline $\begin{array}{l}\text { Coagulase- negative } \\
\text { Staphylococci }(n=146)\end{array}$ & $32 \%$ & $\begin{array}{l}27 \\
(25.7 \%)\end{array}$ & $119(34 \%)$ \\
\hline Str. agalactiae $(n=61)$ & $13.4 \%$ & $\begin{array}{l}15 \\
(14.3 \%)\end{array}$ & $46(13 \%)$ \\
\hline Str. dysgalactiae $(n=40)$ & $8.8 \%$ & $9(8.6 \%)$ & 31 (8.8\%) \\
\hline Str. uberis $(n=9)$ & $2 \%$ & $3(2.86 \%)$ & $6(1.7 \%)$ \\
\hline Enterococcus faecalis ( $n=9$ ) & $2 \%$ & $3(2.86 \%)$ & $6(1.7 \%)$ \\
\hline E. coli $(n=113)$ & $24.8 \%$ & $\begin{array}{l}26 \\
(24.7 \%)\end{array}$ & $87(24.8 \%)$ \\
\hline Klebsiella spp. $(n=1)$ & $0.22 \%$ & $1(0.95 \%)$ & - \\
\hline Enterobacter aerogenes $(n=3)$ & $0.66 \%$ & $3(2.86 \%)$ & - \\
\hline $\begin{array}{l}\text { Enterobacter } \\
\text { agglomerans }(n=1)\end{array}$ & $0.22 \%$ & $\begin{array}{l}1 \\
\text { (0.95\%) }\end{array}$ & - \\
\hline Micrococcus spp. $(n=3)$ & $0.66 \%$ & $2(1.9 \%)$ & $1(0.3 \%)$ \\
\hline
\end{tabular}


Table 3. Phenotypic antimicrobial sensitivity pattern of Coagulasenegative Staphylococci isolated from mastitic cows.

\begin{tabular}{llll} 
Antimicrobial agent & \multicolumn{3}{l}{ Antimicrobial agent tested } \\
& S & I & R \\
Ampicillin & $2(10 \%)$ & $1(5 \%)$ & $17(85 \%)$ \\
Oxacillin & - & $3(15 \%)$ & $17(85 \%)$ \\
Ampicillin|sulbactam & $3(15 \%)$ & $5(25 \%)$ & $12(60 \%)$ \\
Cefoxitin & - & $5(25 \%)$ & $15(75 \%)$ \\
Cefotaxime & $5(25 \%)$ & $1(5 \%)$ & $14(70 \%)$ \\
Erythromycin & $7(35 \%)$ & $1(5 \%)$ & $12(60 \%)$ \\
Ciprofloxacin & $12(60 \%)$ & - & $8(40 \%)$ \\
Ofloxacin & $11(55 \%)$ & - & $9(45 \%)$ \\
Sulphamethoxazole/tri & $5(25 \%)$ & - & $15(75 \%)$ \\
methoprim & & & \\
Tetracycline & $6(30 \%)$ & $1(5 \%)$ & $13(65 \%)$ \\
Gentamicin & $9(45 \%)$ & $2(10 \%)$ & $9(45 \%)$ \\
Vancomycin & $19(95 \%)$ & - & $1(5 \%)$ \\
Chloramphenicol & $7(35 \%)$ & $4(20 \%)$ & $9(45 \%)$ \\
N: Number of &
\end{tabular}

$\mathrm{N}$ : Number of isolates, S: Sensitive isolates, I: Intermediate sensitive isolates, and $\mathrm{R}$ : Resistant isolates.

\section{DISCUSSION}

Mastitis is one of the most common infectious diseases that destroy the cow calf business not only in the Egyptian dairy farms but also all over the world [1, 27]

The major causes of mastitis are pathogenic bacteria which play the main role in reducing milk quantity, low quality milk, reduced reproductive efficiency and increase culling rate moreover increase the cost of drugs and veterinary services [28, 29].

Based on history, clinical examination of the udder, California mastitis test (CMT) and bacteriological examination of milk samples, mastitis was diagnosed in the examined cases at Damietta, El-Sharkia and El-Dakahlia governorates. The present study showed that, Out of 415 examined dairy cows, the overall prevalence of mastitis was $54 \%$ at the cattle level which is in close alignment with previous published reports from Bangladesh $53.30 \%$ and Ethiopia $(50.7 \%)$ [30,31]. While, this prevalence was higher than the previous studies from Finland (30.6\%) [32]. This difference in the prevalence rate of mastitis showed among these reports from different regions could be attributed to differences in management and hygienic practices, housing conditions, animal risk factors, causative microorganisms and absence of awareness of farmers to the loss caused by mastitis [21].

The prevalence rate of subclinical mastitis at the level of cattle $42 \%$ was higher than clinical mastitis form $12 \%$. These results were in harmony with the previous research in Ethiopia $43.3 \%$ subclinical mastitis cattle in compared with $22 \%$ as clinical mastitis [33]. While, the prevalence of mastitis on whole quarter level in the present study $52.1 \%$ was in accordance with previous study $45.3 \%$ [34]. Moreover, the rate of subclinical mastitis at the level of quarter in this study $40.3 \%$ was higher than the clinical mastitis $11.8 \%$. Our results were in close agreement with the previous reported rates in Ethiopia $25.3 \%$ subclinical form and $13.4 \%$ the clinical form [35]. This could be due to inappropriate milking hygiene, absence of post milking teat dipping and little care given to subclinical mastitis form because the infected animal did not show any visible signs and secreted apparently normal milk $[21,36]$.
Here, Coagulase-negative Staphylococci were the predominant isolates from clinical and subclinical mastitic cases. Our findings were in accordance with previous studies that have been reported CNS were the most common bacteria in their study with higher prevalence rate $(51.9 \%)$ followed by, S. aureus $(20.3 \%)$, Str. agalactiae (8.8\%), Str. dysgalactiae (5.1\%), Micrococcus species (3.8\%) and Str. uberis (2.5\%), in Ethiopia [37]. Coagulase-negative Staphylococci have usually been identified as minor mastitis pathogens, especially when compared with major pathogens group (S. aureus, Streptococci and Coliforms). This can be attributed to the reason that CNS mastitis is very mild, and usually remains subclinical [38]. Interestingly, there is an accelerating change in the isolation maps of mastitis causing agents irrespective to the differences of region, with recorded virulence changes of these pathogens. In this concern, until recently, CNS was considered to be less virulent and mostly accompanied with subclinical mastitis. However, many studies in North America and Europe now detect that CNS can be isolated from clinical mastitis cases [39]. It is possible due to excessive and unsuitable antibiotic use for treatment of mastitis and sub therapeutic doses as growth promoters; these staphylococcal strains develop antibiotic resistance. Multi-drug resistance was observed against some classes of antibiotics such as methicillin, tetracycline and erythromycin which can limit antibiotic effectiveness.

Our results of antibiotic sensitivity test using the disc-diffusion method for 20 CNS isolates revealed that the highest number of isolates were resistant against Ampicillin and Oxacillin, followed by Cefoxitin, Sulphamethoxazole/Trimethoprim, Cefotaxime, Tetracycline, Ampicillin/Sulbactam, Erythromycin, Chloramphenicol, Gentamicin, Ofloxacin, Ciprofloxacin and Vancomycin. These results were in close alignment with previous research that has been detected CNS isolates showed high resistance against ampicillin (86.7\%) followed by, Sulphamethoxazole/ Trimethoprim (74.9\%) then amoxicillinclavulanic acid (52.5\%) and oxacillin (35.7\%) [40]. However, the isolates were less resistant to ciprofloxacin, erythromycin, gentamicin, cefotaxime and ofloxacin. These findings were in accordance with [41] who stated the high resistance of CNS against cefoxitin and oxacillin (57\%, each), indicating these isolates were methicillin resistant.

In the present study, CNS isolates were resistant to multiple antimicrobial agents. Multi-drug resistance (MDR) was reported as a single strain exhibiting resistance to three or more antimicrobial classes [42]. This result was similar to the previous findings stated that multiple-resistant strains of Staphylococcal bacteria [43]. Interestingly, more multiple resistant CNS than $S$. aureus isolates were found in their study. These results may be attributed to the common use of these drugs in treatment of mastitis in which, $\beta$ lactams, such as penicillin and cephalosporin, play an important role in bovine mastitis. Moreover, CLSI recommended that oxacillin-resistant Staphylococci should be notified as resistant to other $\beta$-lactams $[44,45]$. On the other hand, it has been reported lower resistances to gentamicin, ciprofloxacin, enrofloxacin and chloramphenicol which referred to that these antibiotics were less commonly used [46].

The high rate of sensitivity to Vancomycin is considered due to the very limited use of vancomycin-containing preparations [45]. However, one isolate of CNS were showed resistant to vancomycin, this result was in accordance with the results that have been informed two strains of CNS were resistant to vancomycin and also resistant to methicillin [41]. This was an interesting finding because this antibiotic was not used in dairy cattle farms. Besides, it is no longer used in the veterinary field in 
several countries [47]. The exact mechanism of vancomycin resistance in CNS is still unknown [48]. While, it has been reported that methicillin resistant $S$. aureus (MRSA) strains which were resistant against B-lactam antibiotics may exhibit induced resistance against vancomycin [49]. It has been assumed that CNS resistant to methicillin can act as an important reservoir for antibiotic resistance genes transmission. However, little information exists on CNS resistant to methicillin isolated from the lactating cows $[50,51,52]$.

Furthermore, the antibiotic susceptibility of bacteria differs from one region to another where some countries showed higher resistance rates than others. In the future data, the prevalence of resistance should be used for the establishment of guidelines for the proper antibiotic use in the veterinary field as demonstrated by [53].

The emergence of bacterial strains resistant to antibiotics which affect animal health is a growing alarm for the risk of its effects on the public health of humans. They have the ability to be transmitted directly or indirectly. It is therefore necessary to conduct antibiotic sensitivity tests for these pathogens from a practical and economic point of view [54].

The limitations of our study should be mentioned. This study focused on conventional bacteriological examination for detection of CNS and neglected the diagnosis by molecular techniques. Additionally, the multidrug resistance was proven based on disc diffusion and not on molecular bases. So, further molecular investigation studies should be considered for detection of CNS. Moreover, identification of resistant genes for antibiotic must be investigated in further study.

\section{Conclusion}

Coagulase-negative Staphylococci were the predominant causative agents in both forms, clinical and subclinical mastitis. They showed high resistance rates to Ampicillin, Oxacillin, Cefoxitin, Sulphamethoxazole/Trimethoprim, Cefotaxime, Tetracycline, Ampicillin/Sulbactam and Erythromycin. Attention should be paid for judicious use of antimicrobials depending on antibiogram profiles and restriction of haphazard uses of antibiotics for mastitis treatment should be recommended to the veterinarians and veterinary authorities.

\section{Conflict of interest statement}

The authors declare that there is no any conflict of interest in the current research work .

\section{Research ethics committee permission}

This study was permitted by Research ethics committee, Faculty of Veterinary Medicine, Mansoura University

\section{Authors' contribution}

H. T. performed the clinical and laboratory studies, and drafted the manuscript; S.A. processed the data; E.E. drafted the manuscript; M.E. edited the manuscript; M.E. final editing of the manuscript.

\section{REFERENCES}

[1] Seleim RS, Amany YM, Fahmy BG. Mastitis pathogens: attachmentrelated virulence features, whey protein markers and disinfection in split udder trials of dairy cows. Vet Med J Giza. 2002;50: 405-409.

[2] Ashfaq K, Muhammad G. Pathogens associated with bovine and bubaline mastitis in peri-urban areas of Faisalabad, Pakistan. Pak J Life Soc Sci 2008; 6: 86-88.

[3] Schroeder JW. Bovine mastitis and milking management. Drug therapy. 2012; 8:1-16
[4] Harmon RJ. Physiology of mastitis and factors affecting somatic cell counts. J Dairy Sci 1994; 77:2103-2112.

[5] Zhao X, Lacasse P. Mammary tissue damage during bovine mastitis: causes and control. J Anim Sci 2008; 86:57-65.

[6] Losinger WC. Economic impacts of reduced milk production associated with an increase in bulk-tank somatic cell count on US dairies. J Am Vet Med Assoc 2005; 226:1652-8.

[7] El-Awady HG, Oudah EZ. Genetic and economic analysis for the relationship between udder health and milk production traits in Friesian cows. Asian-Australasian J A S 2011;24:1514-1524.

[8] Keane, Orla M., Kathleen E. Budd, James Flynn, and Finola McCoy. Pathogen profile of clinical mastitis in Irish milk-recording herds reveals a complex aetiology. Vet. Rec. 2013; 173:17.

[9] Awandkar SP, Khode NV, Sardar VM, Mendhe MS. Prevalence and current antibiogram trend of mastitic agents in Udgir and its visinity, Maharashtra State, India. Int. J Dairy Sci 2009; 4:117-22.

[10] Mekonnen $H$, Tesfaye A. Prevalence and etiology of mastitis and related management factors in market oriented smallholder dairy farms in Adama, Ethiopia. Rev Med Vet 2010; 161:574-9.

[11] El-Jakee JK, Aref NE, Gomaa A, El-Hariri MD, Galal HM, Omar SA, Samir A. Emerging of coagulase negative staphylococci as a cause of mastitis in dairy animals: An environmental hazard. IJVSM 2013; 1:74-8.

[12] Pyorala S. Trends and advances in mastitis therapy. In Recent Developments and Perspectives in Bovine Medicine. Keynote Lectures in XXII World Buiatrics Congress, Hannover. Hildesheimer Druck and Verlag GmbH, Hildesheim, Germany. 2002 Aug. 18-23; 360-368

[13] Thorberg BM, Danielsson-Tham ML, Emanuelson U, Waller KP. Bovine subclinical mastitis caused by different types of Coagulase-negative Staphylococci J Dairy Sci 2009; 92:4962-70.

[14] Park JY, Fox LK, Seo KS, McGuire MA, Park YH, Rurangirwa FR, Sischo WM, Bohach GA. Detection of classical and newly described Staphylococcal superantigen genes in Coagulase-negative Staphylococci isolated from bovine intramammary infections. Vet Microbiol 2011; 147:149-54.

[15] McDougall $S$, Hussein $H$, Petrovski K. Antimicrobial resistance in Staphylococcus aureus, Streptococcus uberis and Streptococcus dysgalactiae from dairy cows with mastitis. New Zeal Vet J 2014; 62:6876.

[16] Moroni P, Pisoni G, Antonini M, Villa R, Boettcher P, Carli S. Antimicrobial drug susceptibility of Staphylococcus aureus from subclinical bovine mastitis in Italy. J Dairy Sci 2006; 89:2973-6.

[17] Vishnupriya S, Antony PX, Mukhopadhyay HK, Pillai RM, Thanislass J, Srinivas VM, Kumar RS. Methicillin resistant Staphylococci associated with bovine mastitis and their zoonotic importance. Vet World 2014; 7:422-7.

[18] Walther C, Perreten V. Letter to the editor: Methicillin-resistant Staphylococcus epidermidis in organic milk production. J Dairy Sci 2007; 90:5351.

[19] Bonna IC, dos Santos AP, Teixeira GN, Vieira-da-Motta O. Staphylococcus coagulase-negativos resistentes a drogas isolados de leite de búfalas (Bubalus bubalis). Revta. Bras. Ciênc. Vet. 2007; 14: 117-121.

[20] Soares LC, Pereira IA, Pribul BR, Oliva MS, Coelho SM, Souza M. Antimicrobial resistance and detection of mecA and blaZ genes in Coagulase-negative Staphylococcus isolated from bovine mastitis. Pesq Vet Bras 2012; 32:692-6.

[21] Constable PD, Hinchcliff KW, Done SH, Grünberg W. Veterinary medicine: a textbook of the diseases of cattle, horses, sheep, pigs and goats. Elsevier Health Sciences. 11th ed. Philadelphia, Pennsylvania: WB Saunders 2017:1913.

[22] Clements AC, Taylor DJ, Fitzpatrick JL. Evaluation of diagnostic procedures for subclinical mastitis in meat-producing sheep. J Dairy Res. 2003; 70(2):139-48.

[23] Dego OK, Tareke F. Bovine mastitis in selected areas of southern Ethiopia. Trop Anim Health Pro 2003; 35:197-205.

[24] Quinn P, Markey B, Carter M, Donelly W, Leonard F. Veterinary Microbiology and Bacterial Disease 2002; 1-648.

25] Bauer AW. Antibiotic susceptibility testing by a standardized single disc method. Am J Clin Pathol 1996; 45:149-58.

[26] CLSI: Performance standards for antimicrobial susceptibility testing: Twenty-fourth informational supplement, M100-S24. Wayne P. Clinical and Laboratory Standards Institute (CLSI). 2014; 34:1. 
[27] Miller RH, Paape MJ, Fulton LA, Schutz MM. The relationship of milk somatic cell count to milk yields for Holstein heifers after first calving. J Dairy Sci 1993;76:728-33.

[28] Barker AR, Schrick FN, Lewis MJ, Dowlen HH, Oliver SP. Influence of clinical mastitis during early lactation on reproductive performance of Jersey cows. J Dairy Sci 1998; 81:1285-90.

[29] Sayed M, Rady AA. Acute clinically mastitic animals in villages of Assiut Governance: Diagnosis and Treatment. Vet World 2008;1:261.

[30] Rahman MM, Islam MR, Uddin MB, Aktaruzzaman M. Prevalence of subclinical mastitis in dairy cows reared in Sylhet district of Bangladesh. Int. J. BioRes. 2010; 1:23-28.

[31] Asmare AA, Kassa F. Incidence of dairy cow mastitis and associated risk factors in Sodo town and its surroundings, Wolaitia zone, Ethiopia. Slovak J Anim Sci 2017; 50:77-89.

[32] Pitkälä A, Haveri M, Pyörälä S, Myllys V, Honkanen-Buzalski T. Bovine mastitis in Finland 2001-prevalence, distribution of bacteria, and antimicrobial resistance. J. Dairy sci. 2004; 87:2433-41.

[33] Tadesse A, Chanie M. Study on the occurrence of bovine mastitis in Addis Ababa dairy farms and associated risk factors. Advan. Biol. Res. 2012; 6:151-158.

[34] Lakew M, Tolosa T, Tigre W. Prevalence and major bacterial causes of bovine mastitis in Asella, South Eastern Ethiopia. Trop Anim Health Prod. 2009; 41:1525-1530.

[35] Bedane A, Kasim G, Yohannis T, Habtamu T, Asseged B, Demelash B. Study on prevalence and risk factors of bovine mastitis in Borana pastoral and agro-pastoral settings of Yabello District, Borana zone, Southern Ethiopia. Am-Euras. J. Agric. and Environ. Sci. 2012; 12:127481.

[36] Haftu R, Taddele H, Gugsa G, Kalayou S. Prevalence, bacterial causes, and antimicrobial susceptibility profile of mastitis isolates from cows in large-scale dairy farms of Northern Ethiopia. Trop Anim Health Prod 2012; 44:1765-71.

[37] Bitew M, Tafere A, Tolosa T. Study on bovine mastitis in dairy farms of Bahir Dar and its environs. J Anim Vet Adv 2010; 9:2912-7.

[38] Taponen S, Simojoki H, Haveri M, Larsen HD, Pyörälä S. Clinica characteristics and persistence of bovine mastitis caused by different species of Coagulase-negative Staphylococci identified with API or AFLP. Vet Microbiol 2006; 115:199-207.

[39] Bradley AJ, Leach KA, Breen JE, Green LE, Green MJ. Survey of the incidence and aetiology of mastitis on dairy farms in England and Wales. Vet Rec 2007; 160:253-8.

[40] Fowoyo PT, Ogunbanwo ST. Antimicrobial resistance in Coagulasenegative Staphylococci from Nigerian traditional fermented foods. Ann Clin Microbiol Antimicrob 2017; 16:4.

[41] Kateete DP, Kabugo U, Baluku H, Nyakarahuka L, Kyobe S, Okee M, Najjuka CF, Joloba ML. Prevalence and antimicrobial susceptibility patterns of bacteria from milkmen and cows with clinical mastitis in and around Kampala, Uganda. PloS one 2013; 8:e63413.

[42] Waters AE, Contente-Cuomo T, Buchhagen J, Liu CM, Watson L, Pearce K, Foster JT, Bowers J, Driebe EM, Engelthaler DM, Keim PS. Multidrugresistant Staphylococcus aureus in US meat and poultry. Clin Infect Dis 2011; 52:1227-30.

[43] Cengiz S, Dinc G, Cengiz M. Evaluation of Antimicrobial Resistance in Staphylococcus Spp. Isolated from Subclinical Mastitis in Cows. Pak Vet J 2015; 35: 334-338.

[44] Aarestrup FM, Schwarz S. Antimicrobial resistance in Staphylococci and Streptococci of animal origin. In Antimicrobial resistance in bacteria of animal origin. ASM 2006; 187-212.

[45] Lüthje P, Schwarz S. Antimicrobial resistance of Coagulase-negative Staphylococci from bovine subclinical mastitis with particular reference to macrolide-lincosamide resistance phenotypes and genotypes. J Antimicrob Chemother 2006; 57:966-9.

[46] Sumathi BR, Veeregowda BM, Amitha RG. Prevalence and antibiogram profile of bacterial isolates from clinical bovine mastitis. Vet World 2008; $1: 237-8$.

[47] Daka D, Yihdego D. Antibiotic-resistance Staphylococcus aureus isolated from cow's milk in the Hawassa area, South Ethiopia. Ann. Clin. Microbiol Antimicrob 2012; 11:26

[48] Srinivasan A, Dick JD, Perl TM. Vancomycin resistance in Staphylococci. Clin. Microbiol Rev 2002; 15:430-8.

[49] Gundogan N, Citak S, Yucel N, Devren A. A note on the incidence and antibiotic resistance of Staphylococcus aureus isolated from meat and chicken samples. Meat Sci 2005; 69:807-10.

[50] Feßler AT, Billerbeck C, Kadlec K, Schwarz S. Identification and characterization of methicillin-resistant Coagulase-negative Staphylococci from bovine mastitis. J. Antimicrob. Chemother 2010; 65:1576-82.

[51] Zmantar T, Kouidhi B, Miladi H, Bakhrouf A. Detection of macrolide and disinfectant resistance genes in clinical Staphylococcus aureus and Coagulase-negative Staphylococci. BMC Res. 2011; 4:453.

[52] França CA, Peixoto RM, Cavalcante MB, Melo NF, Oliveira CJ, Veschi JL, Mota RA, Costa MM. Antimicrobial resistance of Staphylococcus spp. from small ruminant mastitis in Brazil. Pesq Vet Bras 2012; 32:747-53.

[53] Hendriksen RS, Mevius DJ, Schroeter A, Teale C, Meunier D, Butaye $P$, Franco A, Utinane A, Amado A, Moreno M, Greko C. Prevalence of antimicrobial resistance among bacterial pathogens isolated from cattle in different European countries: 2002-2004. Acta Vet Scand 2008; 50:28.

[54] Kaliwal BB, Sadashiv SO, Kurjogi MM, Sanakal RD. Prevalence and antimicrobial susceptibility of Coagulase-negative Staphylococci isolated from bovine mastitis. Vet World 2011; 4:158 